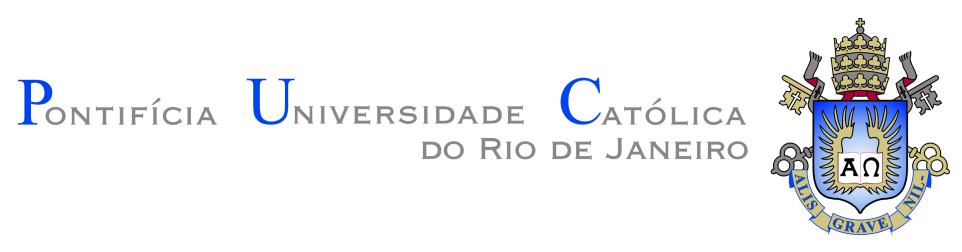

Lucas Aguiar

\title{
Um estudo sobre a taxa de ocupação média dos estádios brasileiros de futebol
}

Trabalho de Conclusão de Curso

Trabalho de Conclusão de Curso, apresentado ao programa de graduação em Administração da PUC-Rio como requisito parcial para obtenção do título de graduação em Administração da PUCRio.

Orientador: Prof. Marco Aurélio de Sá Ribeiro

Rio de Janeiro

Novembro de 2017 
Pontifícia Universidade $C_{\text {atólica }}$

Lucas Aguiar

\section{Um estudo sobre a taxa de ocupação média dos estádios brasileiros de futebol}

Trabalho de Conclusão de Curso, apresentado ao programa de graduação em Administração da PUC-Rio como requisito parcial para obtenção do título de graduação em Administração da PUCRio. Aprovada pela Comissão Examinadora abaixo assinada.

Prof. Marco Aurélio de Sá Ribeiro

Orientador

Departamento de Administração - PUC-Rio

Rio de Janeiro, 21 de Novembro de 2017 
Todos os direitos reservados. É proibida a reprodução total ou parcial do trabalho sem autorização da universidade, do autor e do orientador.

\section{Lucas Aguiar}

Ficha Catalográfica

Aguiar, Lucas

Um estudo sobre a taxa de ocupação média dos estádios brasileiros de futebol / Lucas Aguiar; orientador: Marco Aurélio de Sá Ribeiro. - Rio de janeiro: PUC-Rio, Departamento de Administração, 2017.

v., 40 f: il. color. ; $30 \mathrm{~cm}$

Trabalho de Conclusão de Curso) - Pontifícia Universidade Católica do Rio de Janeiro, Departamento de Administração.

Inclui bibliografia

1. Administração - Teses. 2. Marketing Esportivo;. 3. Estádios de Futebol no Brasil;. 4. Futebol;. 5. Torcedores;. 6. Taxa de Ocupação Média..

I. de Sá Ribeiro, Marco Aurélio. II. Pontifícia Universidade Católica do Rio de Janeiro. Departamento de Administração. III. Título. 


\section{Agradecimentos}

Agradeço ao meu pai, Jayme, que além de sempre me incentivar e apoiar durante toda a minha jornada na universidade, foi o principal responsável por eu gostar de esportes e por ter inserido o Fluminense na minha vida desde pequeno.

À minha mãe, Clicinia, pelo amor, incentivo e apoio incondicional em todos os anos da minha vida.

Ao meu irmão, Breno, pelo companheirismo incondicional em toda a minha vida.

Aos meus avós, por todos os importantes ensinamentos passados.

Ao meu orientador, Marco Aurélio de Sá Ribeiro, por todo o auxílio prestado durante o processo de elaboração deste trabalho.

Aos amigos Carlos Novello e Marcelo Nesci, pelas orientações e dicas para essa pesquisa.

A todos que contribuíram na realização e divulgação do questionário. 


\section{Resumo}

Aguiar, Lucas; de Sá Ribeiro, Marco Aurélio. Um estudo sobre a taxa de ocupação média dos estádios brasileiros de futebol. Rio de Janeiro, 2017. 40p. Trabalho de Conclusão de Curso Departamento de Administração, Pontifícia Universidade Católica do Rio de Janeiro.

Este trabalho teve como objetivo analisar os principais fatores que contribuem para a atual baixa taxa de ocupação média dos estádios brasileiros de futebol. Dessa forma, optou-se por analisar os seguintes aspectos capazes de influenciar essa taxa: desempenho da equipe no campeonato, baixa importância do jogo, alta precificação do ingresso, violência, localização e dificuldade de acesso ou transporte ao estádio, horário do jogo, transmissão da TV, dificuldade na compra dos ingressos, baixa qualidade dos serviços oferecidos pelo estádio e probabilidade de baixo público. O método adotado foi a realização de uma pesquisa descritiva, com abordagem quantitativa. Utilizou-se uma pesquisa eletrônica para coleta de dados. Buscando-se responder ao objetivo geral, foi observado que o conjunto de fatores abordados e também uma equivocada análise na construção dos estádios no passado são determinantes da baixa taxa de ocupação média atual.

\section{Palavras-chave}

Marketing Esportivo; Estádios de Futebol no Brasil; Futebol; Torcedores; Taxa de Ocupação Média. 


\title{
Abstract
}

\begin{abstract}
Aguiar, Lucas; de Sá Ribeiro, Marco Aurélio (Advisor). A study regarding the average occupation rate of Brazilian soccer stadiums. Rio de Janeiro, 2017. 40p. Undergraduate Project Departamento de Administração, Pontifícia Universidade Católica do Rio de Janeiro.
\end{abstract}

This work aims to analyze the main factors that contribute to the actual low average occupancy rate in Brazilian football stadiums. Thus, the research aims to analyze the following factors that are able to affect this rate: team performance in the championship, low importance of the game, high ticket pricing, violence, location and difficulty of access or transport to the stadium, match time, TV transmission, difficulty in buying tickets, low quality of the services provided in the stadiums and low public likelihood. The adopted method was the realization of a descriptive research, with a quantitative approach. An electronic survey was used to collect data. Seeking to meet the general objective, it was observed that the set of factors addressed and also a mistaken analysis in the construction of stadiums in the past are determinants of the current low average occupancy rate.

\section{Keywords}

Sport Marketing Brazilian Football Stadium Football; Sport fans; Average occupancy rate; 


\section{Sumário}

1 O tema e o problema de estudo $\quad 10$

$\begin{array}{lll}1.1 & \text { Introdução } & 10\end{array}$

$\begin{array}{lll}1.2 & \text { Objetivo do estudo } & 13\end{array}$

$\begin{array}{lll}1.3 & \text { Objetivos intermediários do estudo } & 13\end{array}$

$\begin{array}{lll}1.4 & \text { Delimitação e foco do estudo } & 13\end{array}$

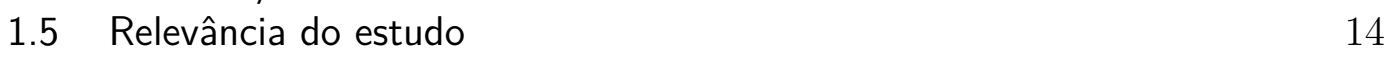

2 Revisão Bibliográfica $\quad 15$

$\begin{array}{ll}2.1 & \text { Marketing Esportivo } \\ 2.2 & 15\end{array}$

$\begin{array}{lll}2.2 & \text { Consumidor Esportivo } & 17\end{array}$

2.3 Aspectos que Influenciam a Satisfação do Consumidor Esportivo 20

3 Metodologia $\quad 25$

3.1 Universo e Amostra 25

$\begin{array}{ll}3.2 & \text { Aplicação do método } \\ \end{array}$

4 Apresentação e análise dos resultados $\quad 27$

$\begin{array}{lll}4.1 & \text { Caracterização da amostra } & 27\end{array}$

4.2 Definição das equipes e frequência de ida à estádios 29

4.3 Fatores que influenciam a baixa taxa de ocupação nos estádios brasileiros de futebol 30

5 Conclusões e constribuições do estudo 33

$\begin{array}{ll}\text { Referências bibliográficas } & 36\end{array}$

A Apêndice - Questionário Aplicado na Pesquisa 38 


\section{Lista de figuras}

Figura 1.1 Campeonatos de futebol com maiores médias de público. 10

Figura 1.2 Os 25 Campeonatos com maior taxa de ocupação no mundo.

Figura 1.3 Média anual de público no ano de 2016.

Figura 2.1 Diferentes formas de aquisição de renda.(4) 16

Figura 2.2 Influências no comportamento do consumidor esportivo.(3) 18

$\begin{array}{lll}\text { Figura 2.3 Escada do envolvimento dos torcedores.(2) } & 19\end{array}$

Figura 2.4 Modelo de rede da atitude do torcedor.(10) 21

Figura 2.5 Influenciadores da satisfação de espectadores com ingresso para toda a temporada.(11) 22

Figura 2.6 Relação entre a identificação com grupo externo, com time e lealdade ao time.(12) 23

Figura 2.7 Fatores específicos do estádio com efeito direto na frequência dos torcedores.(13) 23

Figura 2.8 Fatores do esporte, resposta afetiva e resposta comportamental.(14) 


\section{Lista de tabelas}

Tabela 4.1 Distribuição da amostra por gênero. 27

$\begin{array}{lll}\text { Tabela 4.2 } & \text { Distribuição da amostra por faixa etária. } & 27\end{array}$

Tabela 4.3 Distribuição da amostra por estado civil. 28

Tabela 4.4 Distribuição da amostra por grau de escolaridade. 28

Tabela 4.5 Distribuição da amostra por classe social. 28

Tabela 4.6 Distribuição da amostra pelo time para o qual os repondentes torcem.

Tabela 4.7 Distribuição da amostra pelo número de vezes que os respondentes constumam ir a estádios de futebol ao ano.

Tabela 4.8 Distribuição da amostra pelos fatores que mais influenciam a ida dos respondentes aos estádios.

Tabela 4.9 Distribuição da amostra pelos fatores que mais influenciam a não ida dos respondentes aos estádios.

Tabela 4.10 Distribuição da amostra de acordo com a probabilidade de um maior interesse em ir ao estádios de futebol caso a taxa de ocupação fosse alta. 


\section{O tema e o problema de estudo}

\section{1}

\section{Introdução}

O futebol é a maior paixão dos brasileiros. Segundo pesquisa realizada pelo IBOPE (2012), cerca de $77 \%$ da população do país definiu o esporte criado na Inglaterra no século 19 e que se tornou a atividade esportiva mais popular e praticada no mundo como sendo a sua maior paixão. No entanto, essa preferência não tem sido demonstrada nos estádios brasileiros de futebol.

A Pluri Consultoria, especializada em esportes, realizou um levantamento no ano de 2014 com os vinte campeonatos de futebol que possuem as maiores médias de público do mundo conforme exposto na Figura 1.1.

\begin{tabular}{|c|c|c|c|c|c|}
\hline \multicolumn{6}{|c|}{ CONFRA O RANKNG DE 2014} \\
\hline POSIÇAOO & PAIS & TORCIDA & POSIÇÁOO & PAís & TORCIDA \\
\hline $1^{0}$ & Alemanha & 45.083 & $11^{0}$ & Alemanha (Sére B) & ) 17.491 \\
\hline $2^{0}$ & Inglaterra & 34,604 & 120 & Japáo & 16.434 \\
\hline $3^{0}$ & Espanha & 26.867 & $13^{\circ}$ & Inglaterra (Série B) & 16.438 \\
\hline $4^{0}$ & Itália & 23.053 & $14^{\circ}$ & Turquia & 15.014 \\
\hline $5^{0}$ & México & 22.939 & $15^{\circ}$ & Brasil & 14.951 \\
\hline $6^{0}$ & França & 19.191 & $16^{\circ}$ & Austrália & 14.294 \\
\hline $7^{0}$ & Argentina & 20.571 & $17^{\circ}$ & Bélíga & 11.836 \\
\hline $8^{\circ}$ & Holanda & 19.289 & $18^{\circ}$ & Rússia & 11.797 \\
\hline 90 & Estados Unidos & 18.845 & $19^{\circ}$ & Ucrânia & 10.930 \\
\hline $10^{\circ}$ & China & 17.675 & $20^{\circ}$ & Suiça & 10.772 \\
\hline
\end{tabular}

Fonte: Pluri Consultoria, 2014.

Figura 1.1: Campeonatos de futebol com maiores médias de público.

Como podemos analisar na tabela, Alemanha e Inglaterra são sem dúvida os países que possuem as ligas que melhor vendem o seu produto e que devem servir como referência de modelo de gestão. Ambos possuem as maiores médias de público do mundo nos seus campeonatos da Primeira Divisão e além disso, 
são capazes de fornecer um campeonato bastante atrativo nas suas divisões secundárias, que teoricamente possuem equipes de qualidade inferior, e figuram na $11^{\mathrm{a}}$ e $13^{\mathrm{a}}$ posição, respectivamente.

O Campeonato Brasileiro ficou na $15^{\text {a }}$ posição, atrás das segundas divisões da Alemanha e Inglaterra e de países que possuem uma tradição muito menor no futebol do que o Brasil, como Estados Unidos, China, Japão e Turquia.

A Pluri Consultoria também realizou um levantamento no ano de 2014 (Figura 1.2) com os vinte e cinco campeonatos de futebol que possuem as maiores taxas de ocupação média dos estádios.

\begin{tabular}{|c|c|c|c|c|c|c|c|c|}
\hline $\begin{array}{l}\text { Rank } \\
2014\end{array}$ & $\begin{array}{l}\text { Rank } \\
2013\end{array}$ & $\begin{array}{l}\text { Rank } \\
2012\end{array}$ & Pais & Campeonato & $\begin{array}{l}\text { Média de } \\
\text { Público } \\
2014 / \\
2013\end{array}$ & $\begin{array}{c}\text { Taxa de } \\
\text { ocupaçäo } \\
\%-2014 \text { - } \\
2013\end{array}$ & $\begin{array}{c}\text { Taxa de } \\
\text { ocupaçäo } \\
\text { \%-2013- } \\
2012\end{array}$ & $\begin{array}{c}\text { Taxa de } \\
\text { ocupaçáo } \\
\text { \%-2012 } \\
2011\end{array}$ \\
\hline 1 & 1 & 2 & Alemanha & 1.Bundesliga & 43.173 & $97,7 \%$ & $95 \%$ & $93 \%$ \\
\hline 2 & 2 & 1 & Inglaterra & Premier League & 36.589 & $97,5 \%$ & $95 \%$ & $97 \%$ \\
\hline 3 & 3 & 4 & EUA & MLS & 18.743 & $90,7 \%$ & $91 \%$ & $88 \%$ \\
\hline 4 & 4 & 3 & Holanda & Eredivisie & 19.289 & $87,5 \%$ & $90 \%$ & $90 \%$ \\
\hline 5 & 5 & 5 & Espanha & Primera División & 26.867 & $78,1 \%$ & $83 \%$ & $74 \%$ \\
\hline 6 & 9 & 7 & França & Ligue 1 & 20.693 & $72,9 \%$ & $68 \%$ & $70 \%$ \\
\hline 7 & 18 & 12 & Inglaterra & League One $\left(3^{a}\right)$ & 7.574 & $72,3 \%$ & $52 \%$ & $54 \%$ \\
\hline 8 & 6 & 10 & Alemanha & 2.Bundesliga & 17.491 & $70,6 \%$ & $70 \%$ & $59 \%$ \\
\hline 9 & 12 & 6 & Bélgica & $\begin{array}{l}\text { Jupiler Pro } \\
\text { League }\end{array}$ & 11.836 & $67,8 \%$ & $64 \%$ & $73 \%$ \\
\hline 10 & 14 & 18 & Itália & Serie A & 23.365 & $63,0 \%$ & $62 \%$ & $51 \%$ \\
\hline 11 & 15 & 15 & Japão & J. League 1 & 17.160 & $62,3 \%$ & $60 \%$ & $52 \%$ \\
\hline 12 & 10 & 8 & Inglaterra & $\begin{array}{l}\text { Championship } \\
\left(2^{a}\right)\end{array}$ & 16.438 & $62,1 \%$ & $67 \%$ & $68 \%$ \\
\hline 13 & 19 & 16 & Escócia & Premier League & 10.228 & $57,9 \%$ & $57 \%$ & $52 \%$ \\
\hline 14 & 13 & 21 & Rússia & Premier Liga & 11.797 & $56,8 \%$ & $63 \%$ & $48 \%$ \\
\hline 15 & 21 & 19 & Turquia & Süper Lig & 15.014 & $56,4 \%$ & $48 \%$ & $51 \%$ \\
\hline 16 & 22 & 22 & Dinamarca & Superligaen & 7.671 & $56,0 \%$ & $45 \%$ & $47 \%$ \\
\hline 17 & 8 & 14 & Suécia & Allsvenskan & 7.627 & $55,9 \%$ & $68 \%$ & $53 \%$ \\
\hline 18 & 19 & 20 & França & Ligue $2\left(2^{a}\right)$ & 7.420 & $55,8 \%$ & $51 \%$ & $49 \%$ \\
\hline 19 & 20 & 17 & Espanha & Segunda División & 7.223 & $55,3 \%$ & $49 \%$ & $52 \%$ \\
\hline 20 & 17 & 11 & Argentina & Inicial / Final & 20.599 & $55,0 \%$ & $53 \%$ & $56 \%$ \\
\hline 21 & 16 & 13 & Suíça & Raiffeisen & 10.772 & $52,0 \%$ & $58 \%$ & $53 \%$ \\
\hline 22 & 20 & 9 & México & Liga MX & 22.939 & $50,0 \%$ & $53 \%$ & $62 \%$ \\
\hline 23 & 24 & 25 & Ucrânia & Premier Liga & 10.930 & $45,9 \%$ & $44 \%$ & $45 \%$ \\
\hline 24 & 27 & 29 & Portugal & Primeira Lida & 10.217 & $45,8 \%$ & $42 \%$ & $40 \%$ \\
\hline 25 & 30 & 32 & Austrália & A-League & 14.294 & $44,9 \%$ & $39 \%$ & $37 \%$ \\
\hline 34 & 31 & 27 & Brasil & Brasileirão A & 14.951 & $38,6 \%$ & $38 \%$ & $44 \%$ \\
\hline
\end{tabular}

Fonte: Pluri Consultoria, 2014.

Figura 1.2: Os 25 Campeonatos com maior taxa de ocupação no mundo.

Analisando esse levantamento, percebe-se que a Alemanha e a Inglaterra permanecem sendo os países com os melhores resultados, com incríveis taxas 
de ocupação, de $97,7 \%$ e $97,5 \%$ respectivamente.

Outra liga que merece destaque e que tem crescido cada vez mais é a MLS, principal liga de futebol dos Estados Unidos, e que obteve uma média de público de 18.845 pessoas por jogo e taxa de ocupação dos estádios de 90,7\% no ano de 2014, terceira maior do mundo.

O Campeonato Brasileiro de Futebol não conseguiu figurar entre os vinte e cinco campeonatos que possuem a maior taxa de ocupação do mundo, ficando na $34^{\mathrm{a}}$ posição mundial, atrás de ligas como a $3^{\mathrm{a}}$ divisão inglesa. Este fato demonstra que são necessárias diversas melhorias não só no seu produto, mas sim em toda gestão e organização do campeonato em geral.

Dados mais recentes da ESPNFC.com (Figura 1.3) apontam algumas mudanças nas principais médias de público.

\begin{tabular}{|l|l|}
\hline Bundesliga (GER) & 41,968 \\
\hline Premier League (ENG) & 35,516 \\
\hline La Liga (ESP) & 28,076 \\
\hline Liga MX (MEX) & 26,794 \\
\hline Chinese Super League (CHN) & 24,255 \\
\hline MLS (USA) & 21,692 \\
\hline Serie A (ITA) & 21,069 \\
\hline Ligue 1 (FRA) & 20,898 \\
\hline Championship (ENG) & 19,553 \\
\hline 2.Bundesliga (GER) & 19,176 \\
\hline
\end{tabular}

Fonte: ESPNFC.com, 2016.

Figura 1.3: Média anual de público no ano de 2016.

Três países foram capazes de aumentar consideravelmente as suas médias de público: México, China e Estados Unidos, ficando à frente de ligas como a Série A da Itália e a Ligue 1 da França.

A Liga Americana MLS, em especial, têm crescido bastante nos últimos anos, e mesmo sendo somente o $5^{\mathrm{O}}$ esporte mais popular no país segundo pesquisa do site sportsind.com, obteve impressionantes 95,5\% de taxa de ocupação dos seus estádios no ano de 2016.

Enquanto isso, a média de público do Campeonato Brasileiro no ano de 2016 foi de 15.809 pessoas por jogo, somente a $14^{\mathrm{a}}$ maior média de público do mundo. Já a taxa de ocupação dos estádios brasileiros foi novamente de 
cerca de $38 \%$, o que demonstra que os números brasileiros estão praticamente estagnados.

Considerando os fatos apresentados, o seguinte problema de estudo foi elaborado: A grande maioria dos estádios de futebol utilizados pelas equipes da $1^{\text {a }}$ divisão do Campeonato Brasileiro possui uma baixa taxa de ocupação média. Quais as principais causas desse fato?

\section{2}

\section{Objetivo do estudo}

O objetivo final desse estudo é apresentar a consolidação de reflexões sobre as principais causas da baixa taxa de ocupação média dos estádios de futebol utilizados pelas equipes da $1^{\text {a }}$ divisão do Campeonato Brasileiro.

\section{3}

\section{Objetivos intermediários do estudo}

A fim de determinar as principais causas da baixa taxa de ocupação média dos estádios brasileiros, alguns objetivos intermediários serão analisados:

1. Levantamento das taxas de ocupação média dos estádios de futebol utilizados pelas equipes da $1^{\text {a }}$ Divisão do Campeonato Brasileiro;

2. Levantamento das taxas de ocupação média de estádios utilizados em outras ligas de futebol do mundo;

3. Comparar essas taxas.

\section{4}

\section{Delimitação e foco do estudo}

Este estudo irá focar nos estádios de futebol utilizados pelas equipes da $1^{\text {a }}$ Divisão do Campeonato Brasileiro, analisando dados dos últimos cinco campeonatos realizados. Será realizada uma pesquisa descritiva através da internet com foco em pessoas que moram no Rio de Janeiro e possuem um interesse em futebol. 


\section{5}

\section{Relevância do estudo}

Atualmente, existe uma escassez de estudos analisando os principais fatores que levam a demanda média por jogos de futebol nos estádios brasileiros ser baixa. Além disso, a grande maioria deles foca no público médio. O tema aqui tratado possui como foco a taxa de ocupação média, assunto pouco trabalhado por estudiosos dessa área.

Este enfoque diferenciado é muito importante para profissionais do esporte, uma vez que a taxa de ocupação é extremamente importante para a viabilidade financeira do estádio devido ao custo operacional do mesmo estar diretamente ligado ao seu tamanho e infraestrutura.

As descobertas deste estudo poderão ajudar os profissionais da área esportiva a determinar quais são os principais problemas enfrentados por torcedores que desejam ir ao estádio e não o fazem com frequência. Desta forma, poderão analisar melhor os meios e as ações que devem ser tomadas visando ao aumento da frequência de público nos estádios brasileiros.

O aumento da taxa de ocupação média dos estádios também é fundamental para os clubes de futebol, pois os mesmos conseguirão planejar o aumento das receitas oriundas em dias de jogos e possivelmente irão aumentar o seu percentual de vitórias em jogos como mandante, uma vez que os estádios estarão mais cheios e com mais pessoas apoiando os times da casa, fator bastante importante e motivacional para os atletas.

Além disso, uma maior taxa de ocupação é um ponto de relevante importância para patrocinadores, que possuirão mais pessoas visualizando as suas marcas, administradores de estádios ou consórcios, que irão obter mais lucros em dias de jogos e para o Campeonato Brasileiro em geral, que irá melhorar a sua marca e o seu reconhecimento mundial, o que poderá acarretar em maiores investimentos no campeonato e nos clubes. 


\section{2}

\section{Revisão Bibliográfica}

\section{1}

\section{Marketing Esportivo}

De acordo com (1), o "marketing esportivo é o processo de elaborar e implementar atividades de produção, formação de preço, promoção e distribuição de um produto esportivo para satisfazer as necessidades ou desejos de consumidores e realizar os objetivos da empresa". Para eles, o crescimento da indústria do esporte gerou o aumento da concorrência, o que provoca a necessidade da elaboração de novas estratégias para atrair, satisfazer e conquistar a lealdade dos consumidores. Desta forma, eles concluem que as organizações esportivas devem investir nas atividades tradicionais de marketing, tais como: pesquisa de marketing, segmentação de mercado, definição de mercado-alvo, desenvolvimento do plano de marketing e definição do composto mercadológico.

Segundo (2), "o marketing esportivo consiste em todas as atividades designadas a satisfazer as necessidades e desejos dos consumidores esportivos através de processos de troca". Os autores indicam a existência de dois eixos (a) o marketing de produtos e serviços esportivos diretamente para os consumidores; e (b) o marketing de outros produtos e serviços, utilizando-se de promoções esportivas - patrocínios relacionados ao esporte.

Considerando-se as fontes de receita no setor esportivo, (3) destaca como as principais: (a) receitas de bilheteria; (b) concessões e merchandising; (c) direito de imagem dos atletas; (d) direitos de transmissão pela TV. Ressaltase que a indústria do esporte oferece para os seus consumidores tanto produtos como serviços. No entanto, o esporte contém alguns diferenciais em relação a outros negócios, conforme apresentado na Figura 2.1 abaixo.

Tendo em vista a perspectiva da prestação de serviços da indústria esportiva, (4) define seus stakeholders como sendo: (a) jogadores, participantes e torcedores; (b) espectadores, fãs e associados; (c) investidores empresariais e mídia; (d) outros clubes e organizações esportivas; (e) serviços e materiais de apoio; (f) governo e (g) órgãos governamentais esportivos.

Permanecendo no contexto dessa indústria, as atividades e processos dos 


\begin{tabular}{|c|c|}
\hline Categoria & Diferenças \\
\hline $\begin{array}{l}\text { O mercado de } \\
\text { produtos e serviços } \\
\text { esportivos }\end{array}$ & $\begin{array}{l}\text { - As organizaçōes esportivas, ao mesmo tempo, competem e cooperam. } \\
\text { - Os consumidores esportivos consideram-se especialistas, devido à sua identificaçào } \\
\text { pessoal com o esporte e dedicação. }\end{array}$ \\
\hline O produto esportivo & $\begin{array}{l}\text { - Há uma grande oscilação na demanda dos consumidores pelo esporte. } \\
\text { - É intangivel, efêmero, perecivel, subjetivo, inseparável e tende a ser experiencial. } \\
\text { - São produzidos e consumidos simultaneamente. } \\
\text { - São consumidos publicamente e a satisfação é afetada pelo convivio social. } \\
\text { - Não há controle sobre a composição do produto principal. } \\
\text { - Podem ser classificados como produtos tanto de consumo quanto industriais. } \\
\text { - Carrega em si um apelo universal e atinge todos os elementos da vida das pessoas. }\end{array}$ \\
\hline O custo do esporte & $\begin{array}{l}\text { - O custo dos produtos esportivos é geralmente baixo em comparação ao custo total } \\
\text { pago pelo consumidor na sua aquisiçâo. } \\
\text { - As receitas indiretas são, com frequência, maiores que as receitas operacionais diretas. } \\
\text { - Em algumas situaçôes especificas operam sem fins lucrativos. }\end{array}$ \\
\hline $\begin{array}{l}\text { A promoção de } \\
\text { esporte }\end{array}$ & $\begin{array}{l}\text { - Uma exposição muito grande à mídia tem resultado em uma ênfase crescente no } \\
\text { patrocinio como elemento principal do marketing esportivo. } \\
\text { - Uma boa visibilidade do esporte é atrativa para os negócios em termos de associação } \\
\text { por meio do patrocínio. } \\
\text { - A ênfase na promoção pode ser aplicada apenas às ramificações do produto, e não ao } \\
\text { produto principal. }\end{array}$ \\
\hline $\begin{array}{l}\text { A distribuição do } \\
\text { esporte }\end{array}$ & $\begin{array}{l}\text { - O esporte não distribui fisicamente o seu produto. } \\
\text { - O esporte é produzido e consumido simultaneamente. }\end{array}$ \\
\hline
\end{tabular}

Figura 2.1: Diferentes formas de aquisição de renda.(4)

serviços oferecidos aos consumidores de eventos esportivos podem ser divididas em três partes: (i) "parte da frente"; (ii) "parte de trás"; (iii) "circunstanciais" (5). Na "parte da frente" são apontados os fatores que influenciam os consumidores no momento em que os serviços são prestados, como: disponibilidade, conforto e limpeza das cadeiras; limpeza e organização da arena esportiva; atmosfera do evento; disponibilidade e acesso a bebidas e alimentos; entre outros. No segundo caso, encontram-se as situações que antecedem o evento em si, mas que influenciam a experiência vivida pelo espectador, tais como: acesso à arena esportiva; disponibilidade, acesso e segurança do estacionamento; preços e acessos aos ingressos; horário do evento; meios de transporte disponíveis para a ida e volta da arena esportiva; entre outros. Os fatores "circunstanciais" influenciam diretamente a frequência dos consumidores nos eventos esportivos, no entanto, são considerados incontroláveis, como por exemplo: posição na tabela do time para o qual o consumidor torce; qualidade técnica das equipes e a rivalidade entre as equipes que disputarão as partidas.

Para (3), é primordial que as organizações esportivas desenvolvam estratégias voltadas para a conquista de mais espectadores, uma vez que isso tende a aumentar os valores das fontes de receita do setor. (1) e (4) também possuem a mesma linha de pensamento, indicando que no atual nível de crescimento do setor a tendência é que a concorrência aumente consideravelmente, gerando desta forma uma necessidade de adoção de estratégias inovadoras, buscando não somente atrair, mas satisfazer e conquistar a lealdade dos consumidores 
esportivos. Segundo os autores, as organizações e promotores esportivos devem investir tanto em inovação como nas atividades tradicionais de marketing - segmentação de mercado, definição do composto mercadológico, pesquisa de marketing, definição de mercado-alvo e desenvolvimento do plano de marketing.

\section{2}

\section{Consumidor Esportivo}

Segundo (1), o consumidor esportivo pode ser alocado em três tipos de segmentos: (a) prática esportiva - que é ofertado ao consumidor como produto de participação e/ou entretenimento; (b) produtos esportivos - produtos e serviços, como equipamentos esportivos e serviços médicos, oferecidos aos consumidores para a prática de esportes; (c) promoção esportiva - produtos e serviços ofertados para promover o esporte, tais como eventos, patrocínios e brindes, por exemplo. O consumidor esportivo manifesta motivadores distintos para cada um desses segmentos, o que não tende a acontecer na maioria dos produtos ou serviços oferecidos por outros setores.

Os autores também demonstram o amplo conjunto de produtos oferecidos pela indústria do esporte, sugerindo desta forma o nível de complexidade envolvido nas escolhas de seus consumidores, caracterizado como sendo bastante elevado. Neste sentido, (2) ressalta que o consumidor esportivo se apresenta mais vulnerável às influências ambientais e individuais. A Figura 2.2 abaixo retrata um esquema das influências no comportamento desse tipo de consumidor.

O objetivo do modelo representado na figura acima, de acordo com (2), é "lembrar ao profissional de marketing de todos os fatores a serem examinados cuidadosamente para entender e desenvolver o interesse, o envolvimento e o comprometimento do consumidor" no contexto da indústria esportiva. Os autores acreditam que a tomada de decisão do consumidor dessa indústria envolve o processamento de seus conhecimentos, sentimentos e comportamentos. Esses três fatores afetarão diretamente o seu nível de envolvimento com o esporte. A interação entre os seus elementos é representada pelas setas presentes no modelo.

Os autores também apontam os três principais grupos de fatores capazes de influenciar o comportamento dos consumidores esportivos, sendo eles: (i) socialização, envolvimento e comprometimento; (ii) fatores ambientais (que abrangem: outras pessoas significativas, normas e valores culturais, classe, raça, gênero, condições climáticas e geográficas, comportamento de mercado das empresas esportivas e estrutura de oportunidades esportivas); e (iii) fatores 


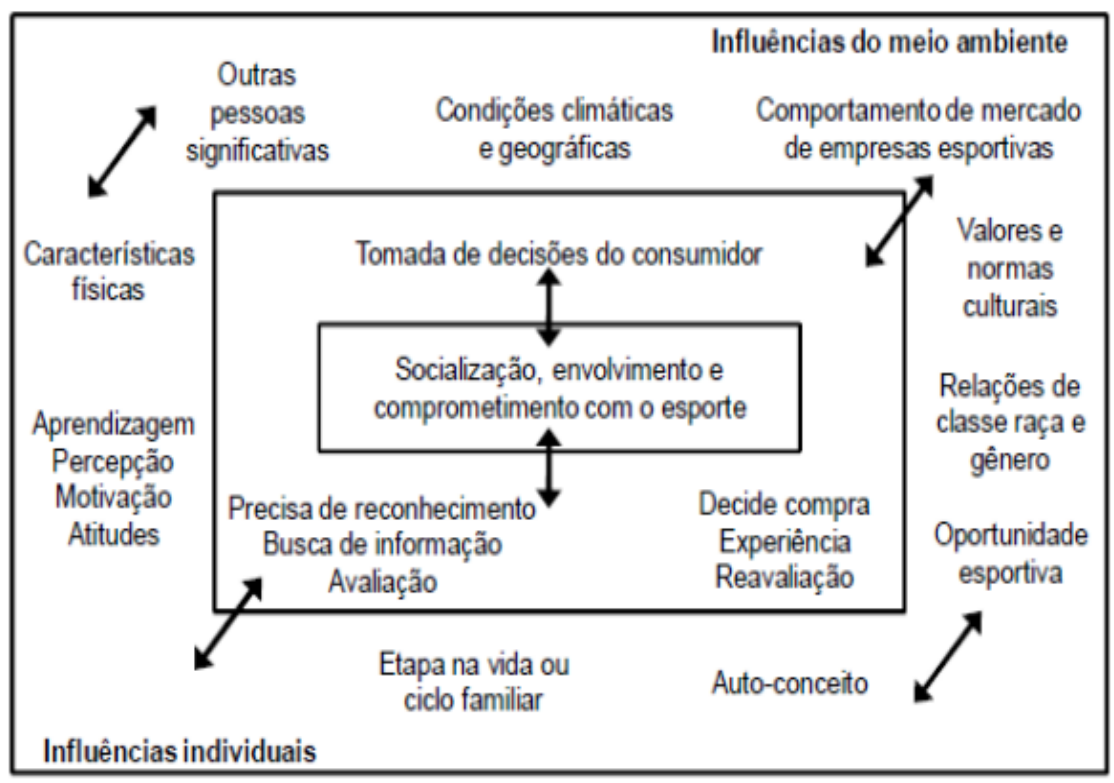

Figura 2.2: Influências no comportamento do consumidor esportivo.(3)

individuais (que abrangem: autoimagem, etapa na vida ou ciclo familiar, características físicas, aprendizagem, percepção, motivação e atitudes).

No entanto, ao avaliar o processo de decisão de compra dos consumidores esportivos, (2) indica seis fases que ultrapassam a tomada de decisões, sendo elas: necessidade de reconhecimento; consciência ou busca de informação; avaliação de escolhas; decisão de compra; vivência esportiva; e avaliação da vivência. Caso ocorra uma satisfação em relação à última fase, tende- e a uma repetição da vivência esportiva, ou seja, uma recorrência do comportamento de consumo. No entanto, caso uma sensação de insatisfação seja observada por parte do consumidor, o mesmo tende a considerar outras opções de consumo, visando desta forma, suprir necessidades semelhantes no futuro.

Segundo (6), a crescente concorrência e esportes novos ou emergentes colaboram para fragmentar o mercado esportivo, tornando mais difícil a atuação das organizações do setor. Eles atribuem as seguintes características a esse mercado dinâmico: (a) ambiente altamente dinâmico; (b) torcedores com expectativas elevadas; (c) conflito entre o conceito de esporte como negócio e como competição; (d) surgimento de novas tecnologias; (e) interesses cada vez mais individuais dos consumidores; (f) mudanças nas estruturas e no comportamento das famílias; (g) falta de tempo dos consumidores.

Os autores também abordam os chamados conectores fundamentais, sendo eles quatro pontos de contato que conectam os torcedores ao esporte. O primeiro é o "astro", que pode envolver um jogador, equipe, torneio, estádio ou qualquer outro elemento que atraia torcedores, transformando-os em 
consumidores segundo (6). A segunda conexão é estabelecida pelo "local", que equivale ao lugar de origem de equipes, atletas e instalações, relacionando-se à necessidade dos torcedores de interação comunitária, filiação e ligação com a região onde moram ou nasceram. Outra conexão é a chamada de "comunicação social", cujos elementos de ligação são: a "moeda social", que aborda o esporte como uma maneira das pessoas de compartilharem informações, incentivando desta forma a interação social; e a "família", devido ao fato de o esporte poder ser considerado um fator de união no ambiente familiar. O último grupo é o de busca, constituído por três formas de conexão: (i) "experiências indiretas", possuindo como catalizador o desejo da pessoa de se envolver e de ter uma maior acessibilidade ao esporte e atletas; (ii) "incerteza", que contempla a imprevisibilidade do esporte; e a (iii) "utopia", que abrange as experiências esportivas que representam o passado do torcedor.

Os mesmos também determinam os seguintes canais de acesso para os torcedores: (a) prática esportiva; (b) mídia; (c) divulgação boca a boca; e (d) mentor - pessoa interessada no envolvimento de outros indivíduos no esporte. Os conectores, assim como os canais de acesso, podem influenciar o grau de envolvimento dos torcedores com o time ou esporte, que é apresentado na Figura 2.3 abaixo.

\begin{tabular}{|l|l|}
\hline Fanáticos & $\begin{array}{l}\text { Os mais persistentes e participantes, tendem a se identificar totalmente com o esporte, } \\
\text { rara-mente faltam com seu apoio à equipe preferida, tanto pessoalmente como } \\
\text { financeiramente }\end{array}$ \\
\hline Conhecedores & $\begin{array}{l}\text { Fäs que têm amplo acesso e intensa participação nos meandros do mundo dos eventos } \\
\text { esportivos }\end{array}$ \\
\hline Agregados & $\begin{array}{l}\text { Torcedores que querem estar sempre junto das equipes e dos seus heróis e ter } \\
\text { oportunidades continuadas de trocar saudaçōes com eles, ou concretizar outra } \\
\text { experiência de interação }\end{array}$ \\
\hline Colecionadores & $\begin{array}{l}\text { Făs sempre dispostos a pagar bem por produtos que de alguma forma simbolizem o } \\
\text { esporte preferido }\end{array}$ \\
\hline Gastadores & Pessoas dispostas a investir grande soma pelo prazer do esporte \\
\hline Curiosos & $\begin{array}{l}\text { Normalmente se relacionam com o esporte por meio da mídia, inclusive para acompanhá- } \\
\text { lo, sendo que raramente comparecem a algum evento esportivo }\end{array}$ \\
\hline Indiferentes & Pessoas que năo tem interesse em esporte \\
\hline
\end{tabular}

Figura 2.3: Escada do envolvimento dos torcedores.(2)

Segundo (4), "os consumidores esportivos podem ser pesquisados, segmentados, perfilados e definidos como alvo, mas a essência do que querem pode ser um mistério! Isso ocorre porque o que desejam é a imprevisibilidade. Eles querem competição!". Devido à essa particularidade, os profissionais de 
marketing possuem um grande desafio acerca da percepção do comportamento do consumidor esportivo.

\section{3}

\section{Aspectos que Influenciam a Satisfação do Consumidor Esportivo}

Segundo (7), "a satisfação é a resposta ao contentamento do consumidor. É o julgamento de que uma característica do produto ou serviço, ou o produto ou o serviço em si, ofereceu (ou está oferecendo) um nível prazeroso de contentamento relativo ao consumo, incluindo níveis maiores ou menores de contentamento".

De acordo com (8), ao considerar a indústria esportiva, apontam cinco dimensões capazes de mensurar a percepção de qualidade de espectadores de esportes profissionais, sendo elas: (a) acesso; (b) confiança; (c) receptividade; (d) tangibilidade; e (e) segurança.

Segundo os autores, os profissionais de marketing devem focar especialmente na qualidade dos serviços de extensão oferecidos aos espectadores. Devido ao fato de que não se pode ter controle acerca do resultado do produto principal, que é o resultado da partida, somente os aspectos do serviço que são considerados extensões do produto, ou seja, os que são independentes do desempenho esportivo em si é que podem ser influenciados, o que traz uma diferenciação na atuação desses profissionais em relação aos de outras áreas.

Seguindo essa linha de pensamento, (9) acreditam que é primordial distinguir as duas dimensões de serviços expostos aos espectadores em eventos esportivos: (a) serviço principal, ou seja, o jogo/partida/evento em si; e (b) serviços periféricos ou estendidos, que contemplam todos os serviços que não se relacionam diretamente ao jogo/partida/evento, como serviços de alimentação, estacionamento, entretenimento nos intervalos, entre outros.

A Rede de Atitude do Torcedor (FAN, do inglês fan attitude network), proposta por (10), apresentada na Figura 2.4 abaixo, sugere um processo por meio do qual a satisfação das necessidades disponíveis serve como um motivador para a identificação com um esporte ou equipe. Essa identificação resultará na atitude do torcedor em relação à equipe ou esporte, que, por sua vez, é capaz de influenciar no estabelecimento da lealdade do torcedor, que uma vez estabelecida, influi diretamente na sua frequência às arenas esportivas para acompanhar a equipe ou esporte predileto.

Os autores em (11) realizaram uma pesquisa buscando investigar os fatores que influenciaram a satisfação dos consumidores que adquiriram ingressos para toda uma temporada da equipe de futebol francesa Olympique de Lyon, e chegaram à conclusão de que a imagem do clube é determinante para 
Internalizaçäa

Formaçāo e mudança da atitude

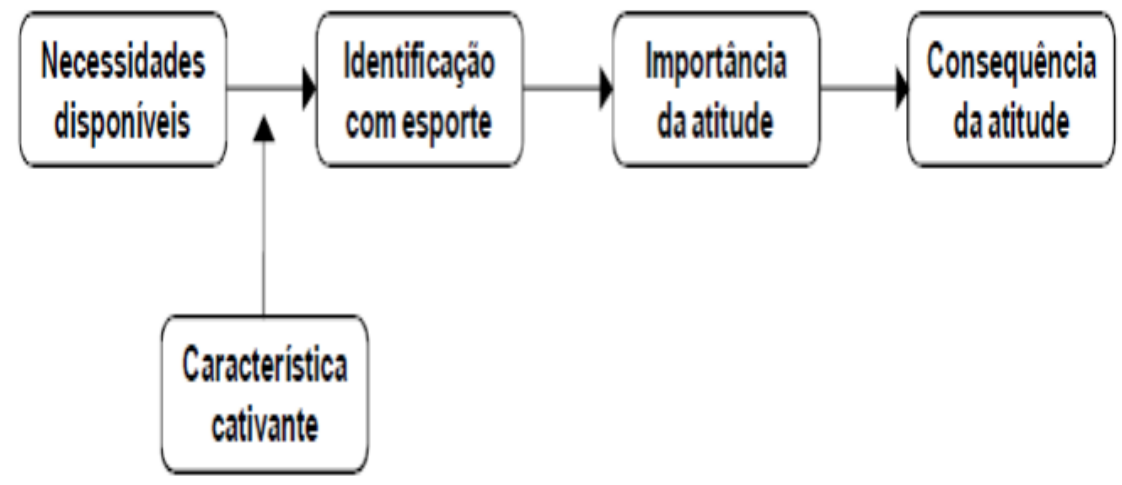

Figura 2.4: Modelo de rede da atitude do torcedor.(10)

a avaliação da satisfação. Além desse fato, a vantagem econômica percebida pelos torcedores que adquiriram esse pacote de ingressos também foi algo destacado pelos autores. Outros elementos motivacionais tais como desempenho da equipe, vontade de se expressar, prazer de ver o espetáculo e interesse pelo esporte também foram expostos no estudo como fatores importantes para torcedores frequentarem os jogos do time comprando ingressos para toda a temporada.

A Figura 2.5 abaixo apresenta o modelo final encontrado pelos autores. Ressalta-se que a única relação negativa existente no modelo se refere à decepção relativa aos resultados obtidos que influenciam negativamente a imagem da equipe.

Segundo (12), torcedores esportivos se julgam parte de uma organização, e não simples consumidores de um produto ou serviço. Dessa forma, com a finalidade de se alcançar uma maior fidelidade do torcedor em relação à sua equipe favorita, sugere-se um investimento na identificação desses indivíduos com o time, considerando sempre o simbolismo dessa identidade. Com isso, os autores apresentam uma visão diferente do torcedor, aonde a identificação com uma equipe também é motivada pela identidade do grupo ao qual esse sujeito pertence. A ideia dos autores é apresentada na Figura 2.6 abaixo.

A utilização de fatores relacionados ao estádio, resposta do espectador e da lealdade como uma variável moderadora para se estudar a frequência dos torcedores nas arenas esportivas é proposta por (13) no seu Modelo do Escopo Esportivo, apresentado na Figura 2.7 abaixo. 


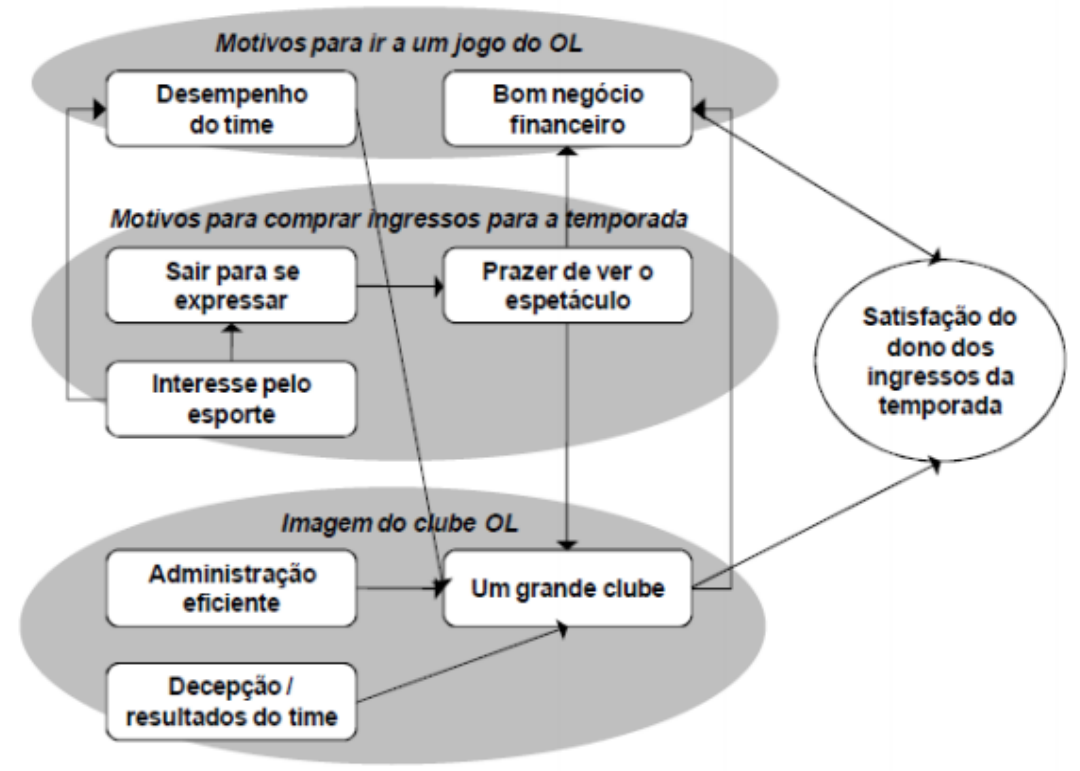

Figura 2.5: Influenciadores da satisfação de espectadores com ingresso para toda a temporada.(11)

Os autores indicam que a combinação de times vitoriosos com torcedores leais geralmente significa uma alta frequência de torcedores nas arenas esportivas. No entanto, os resultados do estudo apontam que, além da lealdade ao time, fatores associados à experiência no estádio, como estacionamento, limpeza, percepção de aglomeração, controle do comportamento de torcedores e serviços de alimentação também influenciam diretamente o desejo do torcedor de permanecer e de regressar à arena.

Considerando que o ambiente físico do estádio seria capaz de representar um efeito considerável de influência na decisão dos espectadores de permanecer e retornar ao estádio, os autores em (14) deram continuidade ao estudo anterior, indicando que aspectos específicos como facilidade de acesso ao estádio, estrutura estética (principalmente relacionada às cores e decoração do estádio), qualidade do placar eletrônico, conforto dos assentos e layout impactam diretamente na percepção de prazer do torcedor, gerando uma resposta afetiva influenciadora da resposta comportamental de voltou ou não a ter a mesma experiência, conforme a Figura 2.8 abaixo.

Por fim, (15) salienta que a satisfação dos torcedores está relacionada à experiência obtida no evento em si, incluindo o resultado da partida. Segundo o autor, a satisfação é fundamental para a retenção do consumidor e possibilita também o "boca a boca" positivo sobre o evento. 


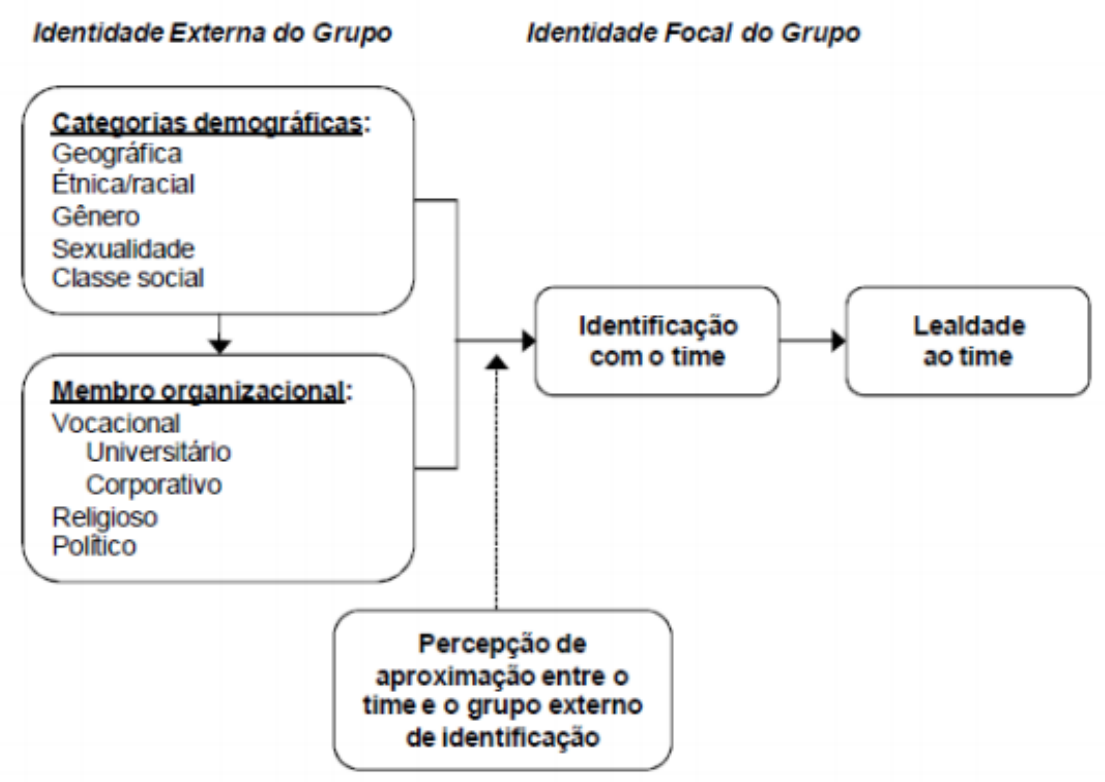

Figura 2.6: Relação entre a identificação com grupo externo, com time e lealdade ao time.(12)

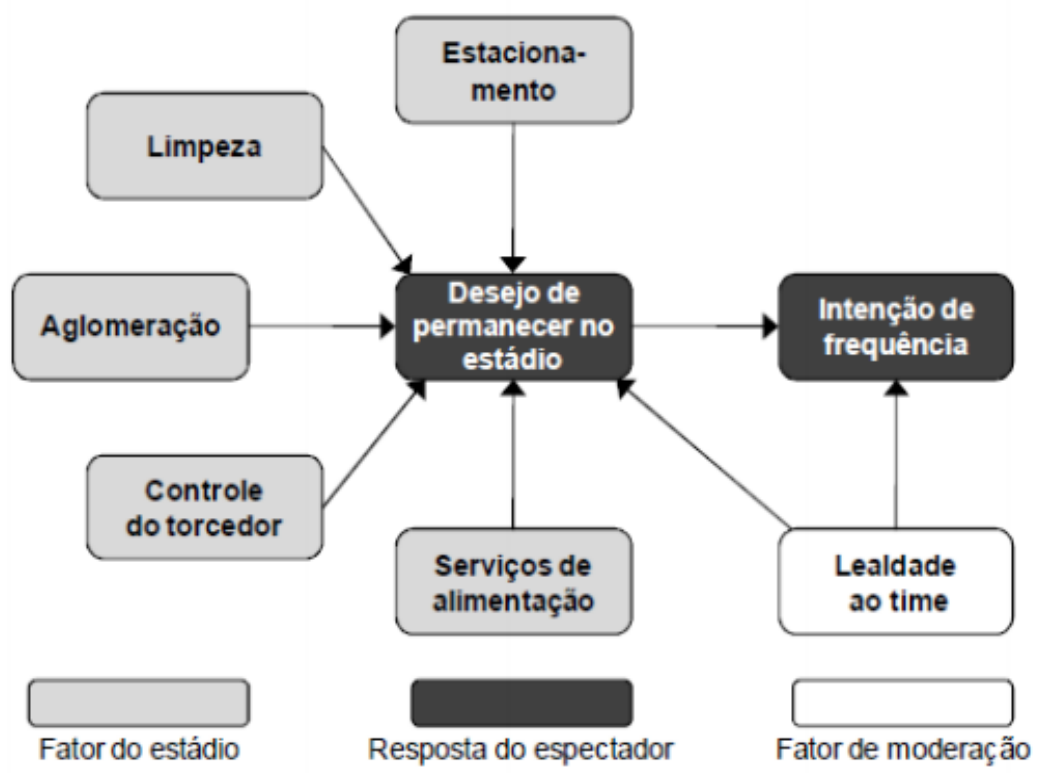

Figura 2.7: Fatores específicos do estádio com efeito direto na frequência dos torcedores.(13) 


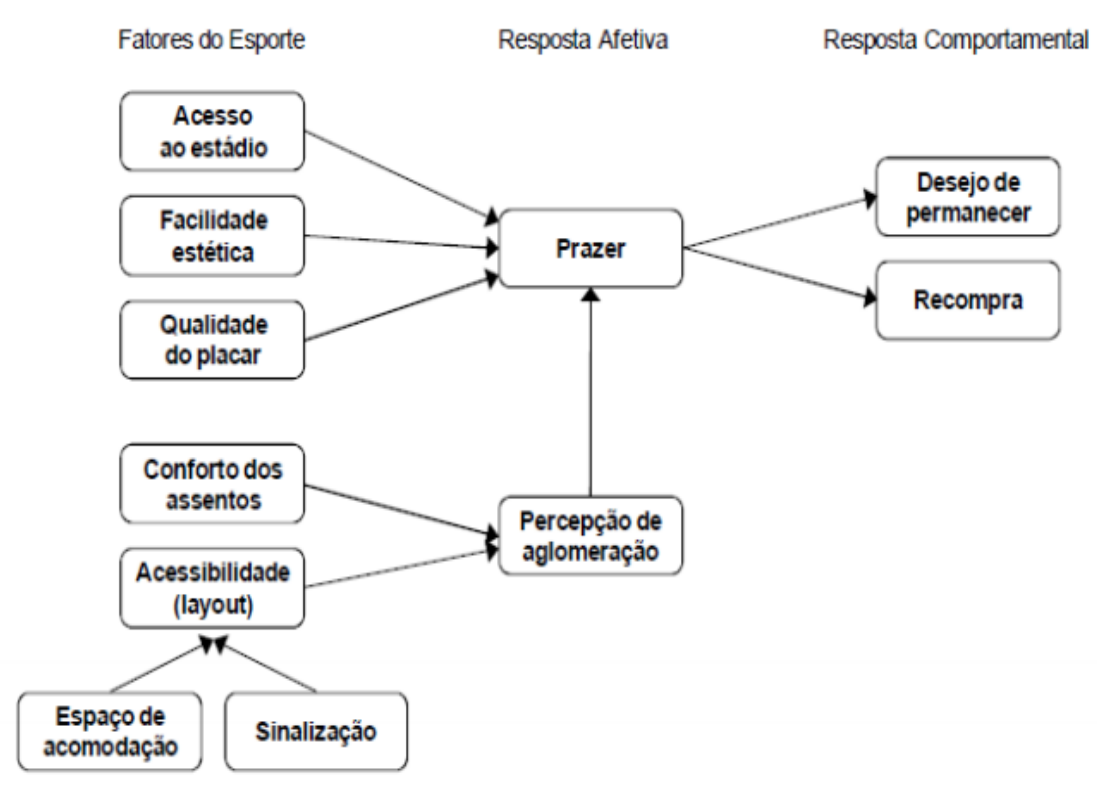

Figura 2.8: Fatores do esporte, resposta afetiva e resposta comportamental.(14) 


\section{3 \\ Metodologia}

Visando um maior entendimento acerca dos principais motivos que fazem as pessoas tomarem a decisão de ir ou não a um estádio de futebol, foi realizada uma pesquisa descritiva, uma vez que ela "analisa e correlaciona fatos ou fenômenos (variáveis) sem manipulá-los. Procura descobrir, com a maior precisão possível, a frequência com que um fenômeno ocorre, sua relação e conexão com outros" (16). No entanto, ela também possui características de uma abordagem explicativa, uma vez que busca "identificar os fatores que determinam ou que contribuem para a ocorrência de fenômenos" (17).

Foi utilizada uma pesquisa para a coleta de dados, definida por (18) como "uma metodologia positivista na qual uma amostra de sujeitos é retirada de uma população e estudada para se fazerem inferências sobre esta população". Permitiu-se ao próprio entrevistado a responder o questionário pela internet, o que a caracteriza como sendo uma pesquisa eletrônica (19).

\section{1}

\section{Universo e Amostra}

O público que poderia participar da pesquisa precisava possuir duas características: (a) torcer para algum time de futebol brasileiro; e (b) demonstrar interesse em futebol.

O primeiro filtro foi utilizado a fim de analisar se a identificação e a lealdade a uma equipe de futebol brasileira são capazes de influenciar, direta ou indiretamente, a intenção da pessoa de retornar ao estádio e a satisfação obtida pela experiência. Já o segundo filtro foi aplicado uma vez que caso a pessoa não possuísse um interesse em futebol, dificilmente ela iria aos estádios e seria pouco influenciada pelos fatores abordados no estudo, o que poderia afetar os resultados obtidos pela pesquisa.

O tipo de amostra adquirida neste estudo foi a não probabilística, definida por (19) como a seleção de elementos sem necessariamente o objetivo de serem estatisticamente representativos da população. Desta forma, os indivíduos da população não necessariamente possuem a mesma chance de serem selecionados para a amostra. Com isso, foi utilizada a amostragem por conveniência, uma vez que foram selecionados membros da população que poderiam proporcionar 
as informações necessárias e estavam mais acessíveis para a participação do estudo (19).

A divulgação do link da pesquisa foi realizada basicamente através do aplicativo Whatsapp, com o pesquisador solicitando em grupos de amigos a participação e também a colaboração dos mesmos divulgando o link da pesquisa em outros grupos nos quais eles participavam, a fim de alcançar o maior número de pessoas possível. Resolveu-se priorizar a participação de pessoas relativamente próximas do pesquisador e de amigos do pesquisador visando à uma maior confiabilidade dos resultados obtidos.

Um total de 235 respostas válidas foram obtidas pelo questionário. Tal questionário foi disseminado via internet através da plataforma Google Formulários. Destaca-se também que os respondentes gastaram em média cerca de 2 minutos para responder a pesquisa.

\section{2}

\section{Aplicação do método}

O roteiro do questionário foi composto basicamente por três etapas. A primeira seção foi composta por diversas perguntas de caráter pessoal, com o objetivo de obter dados suficientes para traçar o perfil característico de cada respondente. Uma vez obtidas essas informações, foi aberta a possibilidade de se analisar os resultados levando em conta aspectos básicos de cada pessoa como por exemplo gênero, idade, escolaridade, entre outros.

A segunda parte foi composta pela definição da equipe pela qual o respondente tem preferência e a frequência pela qual ele costuma ir a estádios de futebol por ano, com o objetivo de familiarizar o pesquisador acerca dos clubes pelos quais as pessoas que responderam mais torcem e também a quantidade de vezes que elas normalmente vão a jogos de futebol ao ano.

A última seção, considerada a mais importante para o estudo abordado, foi caracterizada pela definição dos principais fatores pelos quais os respondentes acreditavam influenciar a ida ou não ida dos mesmos aos estádios de futebol para acompanhar as suas equipes ao vivo. Foram disponibilizadas 10 opções de respostas, tanto para os fatores que mais influenciavam a ida quanto para os fatores que mais influenciavam a não ida às arenas. As pessoas analisadas deveriam escolher exatamente três fatores em cada questão, os quais elas deveriam julgar serem os mais importantes para cada decisão.

Para finalizar o questionário foi elaborada uma pergunta na qual buscouse avaliar a existência de um aumento na intenção das pessoas que realizaram a pesquisa em ir aos jogos caso os estádios de futebol brasileiro possuíssem uma maior taxa de ocupação. 


\section{Apresentação e análise dos resultados}

Através da realização do questionário, foram obtidos dados bastante relevantes acerca dos principais fatores que levam à atual baixa taxa de ocupação dos estádios brasileiros de futebol. Desta forma, os números apresentados nesse capítulo ilustrarão os dados obtidos, assim como o seu resultado final.

\section{1}

\section{Caracterização da amostra}

A seguir descreve-se o perfil da amostra, que primeiramente foi dividida por gênero, conforme apresentado na Tabela 4.1 .

Tabela 4.1: Distribuição da amostra por gênero.

\begin{tabular}{|c|c|c|}
\hline Gênero & Frequência & Porcentagem \\
\hline Masculino & 201 & $85,5 \%$ \\
\hline Feminino & 34 & $14,5 \%$ \\
\hline Total & 235 & $100,0 \%$ \\
\hline
\end{tabular}

Nota-se que a grande maioria dos respondentes é do sexo masculino, atingindo $85,5 \%$ contra $14,5 \%$ do sexo feminino.

A faixa etária da amostra é apresentada na Tabela 4.2 a seguir.

Tabela 4.2: Distribuição da amostra por faixa etária.

\begin{tabular}{|c|c|c|}
\hline Idade & Frequência & Porcentagem \\
\hline Até 15 anos & 5 & $2,1 \%$ \\
\hline Entre 15 e 20 anos & 24 & $10,2 \%$ \\
\hline Entre 21 e 30 anos & 107 & $45,5 \%$ \\
\hline Entre 31 e 40 anos & 39 & $16,6 \%$ \\
\hline 41 anos ou mais & 60 & $25,5 \%$ \\
\hline Total & 235 & $100,0 \%$ \\
\hline
\end{tabular}

Analisando a distribuição da amostra por faixa etária, nota-se que a faixa etária que obteve a maior porcentagem foi a que possuía entre 21 e 30 anos $(45,5 \%)$, mesma faixa etária do pesquisador.

O estado civil dos entrevistados também foi analisado (Tabela 4.3). 
Tabela 4.3: Distribuição da amostra por estado civil.

\begin{tabular}{|c|c|c|}
\hline Estado Civil & Frequência & Porcentagem \\
\hline Solteiro & 143 & $60,9 \%$ \\
\hline Casado/União Estável & 83 & $35,3 \%$ \\
\hline Separado & 7 & $3,0 \%$ \\
\hline Viúvo & 2 & $0,9 \%$ \\
\hline Total & 235 & $100,0 \%$ \\
\hline
\end{tabular}

Com relação à distribuição da amostra por estado civil, nota-se que a maioria dos entrevistados atualmente se encontram solteiros (60,9\%). Outra grande parcela atualmente está casada ou em união estável (35,3\%), enquanto uma pequena parte se encontra separada ou viúva $(3,9 \%)$.

A análise do grau de escolaridade dos respondentes é apresentada na Tabela 4.4.

Tabela 4.4: Distribuição da amostra por grau de escolaridade.

\begin{tabular}{|c|c|c|}
\hline Escolaridade & Frequência & Porcentagem \\
\hline Ensino Fundamental Incompleto & 3 & $1,3 \%$ \\
\hline Ensino Fundamental Completo & 2 & $0,9 \%$ \\
\hline Ensino Médio Incompleto & 4 & $1,7 \%$ \\
\hline Ensino Médio Completo & 17 & $7,2 \%$ \\
\hline Ensino Superior Incompleto & 67 & $28,5 \%$ \\
\hline Ensino Superior Completo & 69 & $29,4 \%$ \\
\hline Pós-Graduação Incompleta & 15 & $6,4 \%$ \\
\hline Pós-Graduação Completo & 58 & $24,7 \%$ \\
\hline Total & 235 & $100,0 \%$ \\
\hline
\end{tabular}

Através dos dados da Tabela 4.4, pode-se destacar três grupos com resultados muito próximos: Ensino Superior Completo (29,4\%), Ensino Superior Incompleto $(28,5 \%)$ e Pós-graduação Completa (24,7\%).

A seguir, a Tabela 4.5 apresenta os dados referentes à Classe Social na qual os respondentes se encontram.

Tabela 4.5: Distribuição da amostra por classe social.

\begin{tabular}{|c|c|c|}
\hline Classe Social & Frequência & Porcentagem \\
\hline Classe A - Renda Familiar Superior a R $\$ 18.740,01$ & 68 & $28,9 \%$ \\
\hline Classe B - Renda Familiar de R $\$ 9.370,01$ a $\mathrm{R} \$ 18.740,00$ & 64 & $27,2 \%$ \\
\hline Classe C - Renda Familiar de R $\$ 3.748,01$ a $\mathrm{R} \$ 9.370,00$ & 73 & $31,1 \%$ \\
\hline Classe D - Renda Familiar de R $\$ 1.874,01$ a $\mathrm{R} \$ 3.748,00$ & 22 & $9,4 \%$ \\
\hline Classe E - Renda Familiar inferior a $\mathrm{R} \$ 1.874,01$ & 8 & $3,4 \%$ \\
\hline Total & 235 & $100,0 \%$ \\
\hline
\end{tabular}


Ao analisar os dados acima, nota-se que três grupos atingiram acima de $25 \%$ das respostas: Classe C $(31,1 \%)$, Classe A $(28,9 \%)$ e Classe B $(27,2 \%)$. Por outro lado, 12,8\% dos entrevistados se consideram parte das Classe D e E, que são as classes que possuem uma maior sensibilidade ao preço dos ingressos. A partir do momento em que o ticket médio dos ingressos aumenta, a quantidade de pessoas pertencentes a esses grupos no estádio diminui.

\section{2}

\section{Definição das equipes e frequência de ida à estádios}

A equipe para a qual os respondentes torcem é demonstrada na Tabela 4.6 a seguir.

Tabela 4.6: Distribuição da amostra pelo time para o qual os repondentes torcem.

\begin{tabular}{|c|c|c|}
\hline Time & Frequência & Porcentagem \\
\hline Flamengo & 83 & $35,3 \%$ \\
\hline Fluminense & 84 & $35,7 \%$ \\
\hline Vasco da Gama & 29 & $12,3 \%$ \\
\hline Botafogo & 20 & $8,5 \%$ \\
\hline São Paulo & 3 & $1,3 \%$ \\
\hline Palmeiras & 4 & $1,7 \%$ \\
\hline Corinthias & 3 & $1,3 \%$ \\
\hline Santos & 1 & $0,4 \%$ \\
\hline Internacional & 2 & $0,9 \%$ \\
\hline Gremio & 1 & $0,4 \%$ \\
\hline Cruzeiro & 1 & $0,4 \%$ \\
\hline Atlético-MG & 2 & $0,9 \%$ \\
\hline Sport Recife & 1 & $0,4 \%$ \\
\hline Bahia & 1 & $0,4 \%$ \\
\hline Total & 235 & $100,0 \%$ \\
\hline
\end{tabular}

Ao analisar os dados da Tabela 4.6, nota-se uma grande preponderância de times do Rio de Janeiro (91,8\%). Além disso, Flamengo e Fluminense foram os clubes que obtiveram os maiores resultados, somando juntos $71 \%$. Ressaltase que devido ao fato de o pesquisador morar no Rio de Janeiro e torcer para o Fluminense, os resultados dessa equipe podem ter sido inflados, uma vez que a pesquisa foi enviada a grupos de amigos do pesquisador que torcem para o mesmo time.

A Tabela 4.7 representa a quantidade de vezes que os entrevistados costumam ir a estádios de futebol ao ano.

Em termos de resposta individual, nota-se que a maioria dos respondentes $(30,2 \%)$ costuma ir a 13 ou mais jogos ao ano, podendo ser considerados como 
Tabela 4.7: Distribuição da amostra pelo número de vezes que os respondentes constumam ir a estádios de futebol ao ano.

\begin{tabular}{|c|c|c|}
\hline Frequência de jogos ao ano & Frequência & Porcentagem \\
\hline Nenhuma & 24 & $10,2 \%$ \\
\hline 1 ou 2 jogos & 50 & $21,3 \%$ \\
\hline Entre 3 e 6 jogos & 42 & $17,9 \%$ \\
\hline Entre 7 e 12 jogos & 48 & $20,4 \%$ \\
\hline 13 jogos ou mais jogos & 71 & $30,2 \%$ \\
\hline Total & 235 & $100,0 \%$ \\
\hline
\end{tabular}

fanáticos. Outros três grupos obtiveram respostas relativamente homogêneas, com 21,3\% das pessoas indo a somente 1 ou 2 jogos, 20,4\% indo entre 7 a 12 jogos e 17,9\% entre 3 e 6 jogos ao ano. Cerca de $10 \%$ dos respondentes não costumam ir a estádios de futebol durante o ano.

\section{3}

\section{Fatores que influenciam a baixa taxa de ocupação nos estádios brasileiros de futebol}

A última parte da pesquisa foi relacionada a fatores que levam as pessoas irem ou não a estádios de futebol. A Tabela 4.8 a seguir demonstra os principais fatores que os entrevistados julgam influenciar a ida deles aos estádios. Cada entrevistado precisava escolher exatamente três fatores, e devido a isso, a porcentagem máxima de cada fator é de $33,3 \%$.

Tabela 4.8: Distribuição da amostra pelos fatores que mais influenciam a ida dos respondentes aos estádios.

\begin{tabular}{|l|c|c|}
\hline Fatores que influenciam a ida ao estádio & Frequência & Porcentagem \\
\hline Importância do Jogo & 120 & $17,0 \%$ \\
\hline Lealdade ao time & 117 & $16,6 \%$ \\
\hline $\begin{array}{l}\text { Localização e acesso/transporte ao estádio } \\
\text { (estacionamento, transporte público e etc.) }\end{array}$ & 79 & $11.2 \%$ \\
\hline Desempenho no campeonato & 78 & $11,1 \%$ \\
\hline Emoção e socialização do torcedor no estádio & 74 & $10,5 \%$ \\
\hline Ida de amigos ou familiares & 72 & $10,2 \%$ \\
\hline Horário do jogo & 61 & $8,7 \%$ \\
\hline Precificação do Ingresso & 58 & $8,2 \%$ \\
\hline Facilidade na compra de ingresso & 41 & $5,8 \%$ \\
\hline $\begin{array}{l}\text { Serviços oferecidos pelo estádio (alimenta- } \\
\text { ção, segurança, limpeza, conforto e etc.) }\end{array}$ & 5 & $0,7 \%$ \\
\hline Total de Votos & 705 & $100,0 \%$ \\
\hline
\end{tabular}

Analisando os resultados obtidos na Tabela 4.8, percebe-se que os fatores que os entrevistados julgam mais importante na hora de ir a um jogo de futebol 
são a importância do jogo $(17,0 \%)$ e a lealdade ao time $(16,6 \%)$.

Além disso, a localização, o acesso e o transporte ao estádio (11,2\%), o desempenho do time no campeonato $(11,1 \%)$, a emoção e a socialização de torcedores que ocorre nas arenas $(10,5 \%)$ e a ida de amigos ou familiares aos jogos $(10,2 \%)$ também são fatores relevantes para os entrevistados.

Outro três fatores possuíram um número significativo de votos, sendo eles o horário do jogo $(8, .7 \%)$, a precificação dos ingressos $(8.2 \%)$ e a facilidade na compra de ingressos $(5,8 \%)$ também são importantes.

Por fim, percebe-se que os serviços oferecidos nos estádios não são fatores considerados fundamentais para a ida aos estádios de futebol brasileiros, uma vez que obteve somente $0,7 \%$ dos votos.

Os fatores que mais influenciam a não ida aos estádios por parte dos entrevistados é apresentado na Tabela 4.9 a seguir. Cada entrevistado precisava escolher exatamente três fatores distintos, e devido a isso, a porcentagem máxima de cada fator é de 33,3\%.

Tabela 4.9: Distribuição da amostra pelos fatores que mais influenciam a não ida dos respondentes aos estádios.

\begin{tabular}{|l|c|c|}
\hline Fatores que influenciam a ida não ao estádio & Frequência & Porcentagem \\
\hline Violência & 128 & $18,2 \%$ \\
\hline Alta precificação dos ingressos & 125 & $17,7 \%$ \\
\hline Horário dos jogos de & 106 & $15,0 \%$ \\
\hline $\begin{array}{l}\text { Localização está- } \\
\text { acesso/transporte dificuldade ao } \\
\text { dio(estacionamento, transporte públicos } \\
\text { e etc.) }\end{array}$ & 102 & $14,5 \%$ \\
\hline Desempenho do time no campeonato & 78 & $11,1 \%$ \\
\hline Baixa importância do jogo & 69 & $9,8 \%$ \\
\hline Dificuldade na compra de ingressos & 45 & $6,4 \%$ \\
\hline $\begin{array}{l}\text { Baixa qualidade nos serviços oferecidos pelo } \\
\text { estádio (alimentação, segurança, limpeza, } \\
\text { conforto e etc) }\end{array}$ & 26 & $3,7 \%$ \\
\hline Transmissão da TV & 17 & $2,4 \%$ \\
\hline Probabilidade de baixo público & 9 & $1,3 \%$ \\
\hline Total DE Votos & 705 & $100,0 \%$ \\
\hline
\end{tabular}

Ao analisar a Tabela 4.9, pode-se inferir que a violência $(18,2 \%)$ e a alta precificação dos ingressos (17,7\%) são os principais fatores que influenciam a não ida das pessoas aos estádios de futebol. No entanto, diversos outros fatores também são significativos na hora de decidir ir ou não a um jogo de futebol no Brasil. 
O horário dos jogos $(15,0 \%)$ e a localização, dificuldade de acesso e o transporte ao estádio $(14,5 \%)$ também atingiram números bastante consideráveis na pesquisa.

Da mesma forma, o desempenho do time no campeonato $(11,1 \%)$ e a baixa importância do jogo $(9,8 \%)$ atingiram números relativamente significativos na investigação.

Por outro lado, fatores como a dificuldade na compra de ingressos $(6,4 \%)$, baixa qualidade nos serviços oferecidos nos estádios (3,7\%), transmissão da TV $(2,4 \%)$ e probabilidade de baixo público $(1,3 \%)$ demonstraram ser razões que influenciam a não ida das pessoas, porém, não foram considerados determinantes pela maioria dos entrevistados.

Finalizando a pesquisa, a Tabela 4.10 demonstra a possibilidade de um maior interesse em ir aos jogos caso os estádios brasileiros de futebol possuíssem uma taxa de ocupação, que atualmente se encontra em cerca de 41\%, maior.

Tabela 4.10: Distribuição da amostra de acordo com a probabilidade de um maior interesse em ir ao estádios de futebol caso a taxa de ocupação fosse alta.

\begin{tabular}{|l|c|c|}
\hline $\begin{array}{l}\text { Maior interesse em ir aos jogos caso os está- } \\
\text { dios possuíssem uma maior taxa de ocupação }\end{array}$ & Frequência & Porcentagem \\
\hline Sim & 149 & $63,4 \%$ \\
\hline Não & 46 & $19,6 \%$ \\
\hline Indiferente & 40 & $17,0 \%$ \\
\hline Total & 235 & $100,0 \%$ \\
\hline
\end{tabular}

Nota-se nessa análise que a maioria das pessoas entrevistadas $(63,4 \%)$ possuiria um maior interesse em ir aos estádios caso eles tivessem uma maior taxa de ocupação média. Ou seja, praticamente duas a cada três pessoas que realizaram a pesquisa declararam que o fato de os estádios na maioria das vezes possuírem um aspecto de vazio acaba influenciando a vontade delas de ir aos jogos de futebol no Brasil. 


\section{5}

\section{Conclusões e constribuições do estudo}

A partir dos resultados obtidos na pesquisa, mostrou-se possível concluir alguns fatos acerca dos principais fatores que levam à atual baixa taxa de ocupação média dos estádios brasileiros de futebol. Primeiramente, podese inferir que não existe uma causa principal. Na verdade, existem diversos fatores, que combinados, acabam por afastar cada vez mais as pessoas de obterem a experiência de assistir aos jogos de futebol ao vivo em um estádio no Brasil, mesmo esse esporte sendo considerado a maior paixão da população.

A violência, considerada como o fator que mais desmotiva as pessoas a irem aos estádios segundo a pesquisa, é, sem dúvida, um dos maiores problemas enfrentados atualmente pelo povo brasileiro. Os números relacionados à violência nas principais cidades do Brasil só têm crescido nos últimos anos, e as pessoas cada vez mais acabam optando por deixar de fazer aquilo que elas realmente gostariam devido a esse fato. Falando especificamente sobre futebol, brigas generalizadas entre "torcidas organizadas de futebol" rivais têm sido registradas constantemente nos dias atuais e trazem com elas um sentimento de impunidade. Segundo dados do site correiobraziliense.com.br, somente entre janeiro e julho de 2017 doze torcedores haviam sido mortos em decorrência dessas brigas dentro ou fora dos estádios, contribuindo significativamente para a diminuição da taxa de ocupação média das arenas.

A Copa do Mundo de 2014 trouxe novos estádios para o país, e também como consequência, um aumento considerável do ticket médio dos ingressos, o que foi apontado como a segunda maior influência de não ida ao estádio. O Flamengo, por exemplo, segundo dados do site indicadoresportivo.com, possui o maior ticket médio brasileiro em 2017 , de cerca de $\mathrm{R} \$ 66$. Um torcedor do clube que queira ir ao jogo, além do ticket de $\mathrm{R} \$ 66$, também terá diversas despesas com transporte, estacionamento, alimentação, bebida, entre outros. Esse aumento nos preços dos ingressos gera um sentimento de elitização do estádio, o que acaba afastando as camadas mais populares e consequentemente diminuindo o público médio da maioria dos estádios.

O horário dos jogos também foi um grande fator determinante na decisão de não ir ao jogo por parte dos entrevistados. Nesse caso, os dias de semana são os que mais são afetados, uma vez que diversos jogos são marcados para 
começar às 21:45 da noite, agradando a TV, mas, no entanto, desagradando quem gostaria de assistir aos jogos nos estádios. Esses jogos acabam por volta das 23:45 da noite, horário em que existe um aumento da já temida violência, grande dificuldade de transporte público, e também uma diminuição na quantidade de horas dormidas por parte das pessoas, que na maioria das vezes precisam acordar cedo no dia seguinte para trabalhar e só conseguiriam chegar em casa de madrugada.

Outro fator bastante citado foi a localização do estádio e a dificuldade de acesso ao mesmo. No Brasil, pessoas que não moram perto do local do jogo na maioria das vezes precisam enfrentar diversos desafios para chegar ao estádio. Problemas como engarrafamentos, falta de estacionamento próximo, dificuldade de transportes públicos, entre outros, são constantes, e acabam influenciando diretamente na motivação das pessoas em ir às partidas.

O desempenho do time no campeonato e a baixa importância do jogo também influenciam bastante a decisão das pessoas. Por mais que elas se considerem leais, a partir do momento em que a equipe não está obtendo resultados satisfatórios ou estejam sendo realizados jogos de baixa importância constantes, a vontade do torcedor ir ao estádio também diminui.

A dificuldade na compra de ingressos, transmissão da TV, baixa qualidade nos serviços oferecidos pelo estádio e a probabilidade de baixo público também foram fatores considerados importantes na decisão de não ir ao estádio por cerca de $41 \%$ das pessoas, e devem assim ser considerados.

Ademais, analisando a última questão do questionário, na qual cerca de duas a cada três pessoas afirmaram que teriam um maior interesse em ir aos estádios caso a taxa de ocupação média deles fosse maior, conclui-se que o fato de essa taxa ser baixa também acaba por influenciar diretamente na mesma. Ou seja, caso as pessoas notassem um maior sentimento de escassez de lugares na maioria dos jogos, elas aumentariam o seu interesse em ir aos mesmos. Esse fato sugere à percepção de que a grande maioria das construções dos estádios brasileiros foi realizada equivocadamente. Ao invés de se priorizar a otimização dos custos operacionais e à uma maior taxa de ocupação média, foram construídas arenas com capacidades muito superiores à média das torcidas, o que trazem por consequência um aspecto, na maioria das vezes, de jogos vazios e custos operacionais cada vez mais defasados em relação ao público, o que acaba afetando diretamente os lucros dos clubes e dos gestores das arenas. Algo que exemplifica esse problema é o fato das equipes do Flamengo e do Fluminense terem apresentado prejuízos financeiros ao utilizar o Maracanã após a reforma para a Copa do Mundo 2014 em alguns jogos, o que não deveria ocorrer, principalmente em equipes grandes e que disputam a 
$1^{\mathrm{a}}$ divisão do Campeonato Brasileiro.

Assim sendo, considera-se que o objetivo de se apresentar os principais motivos da baixa taxa de ocupação média nos estádios brasileiros de futebol foi alcançado. Em relação às contribuições para a gestão de marketing esportivo, acredita-se que os resultados dessa pesquisa possam servir para ajudar os gestores a analisar os pontos falhos nos estádios e nos serviços prestados para que o torcedor compareça aos jogos. Dessa forma, serviços e melhorias advindos dessa constatação podem ser utilizados visando à um aumento na frequência dos torcedores aos estádios, que uma vez alcançado, traria uma série de benefícios como o aumento nos resultados financeiros dos jogos e a melhora da marca e do reconhecimento do Campeonato Brasileiro em geral, o que possivelmente, irá acarretar em maiores investimentos tanto por parte da organização do campeonato quanto por parte dos clubes.

Por fim, acredita-se que essa pesquisa poderá servir como base para que outras pesquisas semelhantes possam vir a ser realizadas no futuro com amostras maiores, mais representativas, e que forneçam informações estatisticamente mais relevantes e confiáveis acerca da taxa de ocupação média dos estádios brasileiros de futebol. 


\section{Referências bibliográficas}

[1] PITTS, B.; STOTLAR, D.. Fundamentos de marketing esportivo: tradução. leda Moriya. São Paulo: Phorte, 2002.

[2] MULLIN, B. J., H. S. . S. W. A.. Marketing esportivo (2a ed.). Porto Alegre: Bookman/Artemd, 2004.

[3] POZZI, L. F.. A grande jogada: teoria e prática do marketing esportivo. 1998.

[4] SUMMERS, J.; MORGAN, M. J.. Marketing esportivo. São Paulo: Thomson Learning, 2008.

[5] TREIN, F.; BARCELLOS, P.. Qualidade dos serviços em estádios de futebol. Anais do Encontro Nacional de Engenharia de Produção, Fortaleza, CE, Brasil, 26, 2006.

[6] REIN, I.. Kotler, philip e shields, b. Marketing esportivo-a reinvenção do esporte na busca de torcedores. Porto Alegre, Bookman, 2008.

[7] OLIVER, R. L.. Emotional expression in the satisfaction response. Satisfaction: A behavioral perspective on the consumer, p. 291-325, 1997.

[8] THEODORAKIS, N.; KAMBITSIS, C. ; LAIOS, A.. Relationship between measures of service quality and satisfaction of spectators in professional sports. Managing Service Quality: An International Journal, 11(6):431-438, 2001.

[9] VAN LEEUWEN, L.; QUICK, S. ; DANIEL, K.. The sport spectator satisfaction model: A conceptual framework for understanding the satisfaction of spectators. Sport Management Review, 5(2):99-128, 2002.

[10] FUNK, D. C.; JAMES, J. D.. The fan attitude network (fan) model: Exploring attitude formation and change among sport consumers. Sport Management Review, 7(1):1-26, 2004.

[11] BECCARINI, C.; FERRAND, A.. Factors affecting soccer club season ticket holders' satisfaction: The influence of club image and fans' motives. European Sport Management Quarterly, 6(1):1-22, 2006. 
[12] HEERE, B.; JAMES, J. D.. Sports teams and their communities: Examining the influence of external group identities on team identity. Journal of Sport Management, 21(3):319-337, 2007.

[13] WAKEFIELD, K. L.; SLOAN, H. J.. The effects of team loyalty and selected stadium factors on spectator attendance. Journal of sport management, 9(2):153-172, 1995.

[14] WAKEFIELD, K. L.; BLODGETT, J. G. ; SLOAN, H. J.. Measurement and management of the sportscape. Journal of sport management, 10(1):15-31, 1996.

[15] MADRIGAL, R.. Cognitive and affective determinants of fan satisfaction. Journal of leisure research, 27(3):205, 1995.

[16] CERVO, AMADO L.; BeRVIAN, P. A. D. S. R.. Metodologia científica. 6. ed., 2007.

[17] GIL, A. C.. Métodos e técnicas de pesquisa social. 2008.

[18] COLLIS, J.; HUSSEY, R.. Pesquisa em administração: um guia prático para alunos de graduação e pós-graduação. 2005.

[19] HAIR, J.; BABIN, B.; MONEY, A. ; SAMOUEL, P.. Fundamentos de métodos de pesquisa em administração. 2005. 


\section{A \\ Apêndice - Questionário Aplicado na Pesquisa}

Olá, pessoal!

Meu nome é Lucas Aguiar e eu estou me formando em Administração na PUC-Rio. No questionário abaixo eu busco maiores informaç̃es acerca dos principais fatores que influenciam a baixa taxa de ocupação dos estádios brasileiros de futebol (atualmente a taxa se encontra em cerca de 38\%). Você não levará nem 2 minutos para respondê-lo e estará me ajudando a conseguir o meu sonhado diploma.

Agradeço desde já pela sua contribuição!

1 - Qual o seu gênero?
() Marculino
() Feminino

2 - Qual sua idade?
() Até 15 anos
() Entre 15 e 20 anos
() Entre 21 e 30 anos
() Entre 21 e 40 anos
() 41 anos ou mais

3 - Qual é o seu estado civil?
() Solteiro
() Casado ou em união estável
() Separado
() Viúvo

4 - Qual o seu nível de escolaridade?
() Ensino Fundamental Incompleto
() Ensino Fundamental Completo
() Ensino Médio Incompleto
() Ensino Médio Completo 

() Ensino Superior Incompleto
() Ensino Superior Completo
() Pós-graduação Incompleto
() Pós-graduação Completo

5 - Qual a sua classe social?

() Classe A - Renda familiar superior a $\mathrm{R} \$ 18.740,01$

() Classe B - Renda familiar de $\mathrm{R} \$ 9.370,01$ a $\mathrm{R} \$ 18.740,01$

() Classe C - Renda familiar de $\mathrm{R} \$ 3.748,01$ a $\mathrm{R} \$ 9.370,01$

() Classe D - Renda familiar de $\mathrm{R} \$ 1.874,01$ a $\mathrm{R} \$ 3.748,01$

() Classe E - Renda familiar inferior a $\mathrm{R} \$ 1.874,01$

6 - Qual o seu time?

7 - Com qual frequência você vai a jogos de futebol durante o ano?
() Nenhuma
() 1 ou 2 jogos
() Entre 3 a 6 jogos
() Entre 7 a 12 jogos
() 13 jogos ou mais

8 - Quais fatores mais influenciam a sua ida ao estádio?

() Lealdade ao time

() Desempenho do time no campeonato

() Importância do jogo

() Precificação do ingresso

() Localização e acesso/transporte ao estádio (estacionamento, transporte públicos e etc.)

() Facilidade na compra de ingressos

() Horário do jogo

() Ida de amigos ou familiares

() Serviços oferecidos pelo estádio (alimentação, segurança, limpeza e etc.)

() Emoção e socialização do torcedor no estádio 
9 - Quais fatores mais influenciam a sua não ida ao estádio? (Marque 3 respostas)

() Desempenho do time no campeonato

() Baixa importância do jogo

() Alta precificação do ingresso

() Violência

() Localização e dificuldade de acesso/transporte ao estádio (estacionamento, transporte públicos e etc.)

() Horário do jogo

() Transmissão da TV

() Dificuldade na compra de ingressos

() Baixa qualidade nos serviços oferecidos pelo esstádio (alimentação, segurança, limpeza e etc.)

() Probabilidade de baixo público

10 - Caso os estádio de futebol possuíssem uma maior taxa de ocupação (atualmente cerca de $38 \%$ ) você teria um maior interesse em ir aos jogos?
() $\mathrm{Sim}$
() Não
() Indiferente 